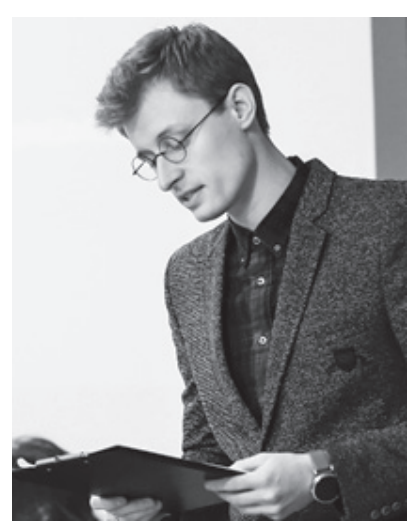

\section{Žydrūnas Vičinskas}

Klaipedos universitetas
Žydrūnas Vičinskas - etnologijos mokslo krypties doktorantas.

Moksliniai interesai: baltų religija ir mitologija, senųjų rašytinių šaltinių verifikacija.

Adresas: Herkaus Manto g. 44-2, LT-92232 Klaipeda.

Tel. $8 \sim 69370870$.

El.paštas: z.vicinskas@gmail.com

Žydrūnas Vičinskas: PhD student of Ethnology.

Research interests: Baltic religion and mythology, the verification of ancient written sources.

Address: Herkaus Manto str. 44-2, LT-92232 Klaipėda.

Phone: 8 69370870.

E-mail: z.vicinskas@gmail.com

\title{
ON THE AUTHENTICITY OF TWO MYTHICAL FRAGMENTS DESCRIBED BY MATTHAEUS PRAETORIUS IN DELICIAE PRUSSICAE OR PRUSSIAN THEATER: RETOLD, RECORDED OR FICTIONAL?
}

\begin{abstract}
Anotacija
Analizuojant ikikrikščioniškąą baltų kultūrą, kurios branduolį sudaro pagoniška religinė logika, iškyla ją fiksuojančios raštijos patikimumo klausimas. Todèl straipsnyje apžvelgiama ir verifikuojama Mato Pretorijaus (Matthäus Prätorius) šaltinyje „Prūsijos įdomybès, arba Prūsijos regykla“ (Deliciae Prussicae, oder Preussische Schaubühne, XVII a. pabaiga) aprašyta mitine informacija, tiesiogiai susijusi su egle bei kriauše. Lygia greta aptariamos žymesnių XIX-XXI a. tyrejjų, nagrinejjusių M. Pretorijaus pateiktą mitinę medžiagą apie eglę ir kriaušę, interpretacijos. XIX-XXI a. tyrimų kontekstas parodè, jog ankstesnių laikotarpių mokslininkai analizuojamos M. Pretorijaus mitinès medžiagos patikimumo nekvestionavo. Tyrimas taip pat leido apčiuopti M. Pretorijaus aprašytų mitinių duomenų, tiesiogiai susijusių su egle bei kriauše, nevienodo patikimumo tendenciją.

PAGRINDINIAI ŽODŽIAI: Matas Pretorijus, egle, kriaušè, autentiškumas, baltų religija ir mitologija.
\end{abstract}

\section{Abstract}

The analysis of the pre-Christian Baltic culture, in the centre of which there is a pagan religious logic, reveals the issue of credibility of its records. Therefore, the article attempts to 
review and to verify mythical material directly related to fir tree and pear tree, described by Matthaeus Praetorius (Matthäus Prätorius) in his manuscript "Deliciae Prussicae or Prussian Theater" (Deliciae Prussicae, oder Preussische Schaubühne, the end of the17th century). In parallel with this, the article discusses interpretations by more significant researchers of the 19th-21st centuries who were concerned with Praetorius's mythical material on fir tree and pear tree. The context of the researches of the 19th, 20th, and 21st centuries has shown that the researchers of earlier periods did not consider the question of reliability of Matthaeus Praetorius's mythical material. The present research also allowed to trace the varying tendency of reliability of Praetorius's described mythical data directly related to fir tree and pear tree.

KEY WORDS: Matthaeus Praetorius, fir tree, pear tree, authenticity, Baltic religion and mythology.

doi:http://dx.doi.org/10.15181/rh.v22i0.1631

\section{Introduction}

The analysis of the pre-Christian Baltic culture, in the centre of which there is a pagan religious logic, reveals the issue of credibility of its records. In previous publications, the authenticity and the research context of gods - Perdoytus, Wejopattis, Gardouten, Bangpitjs, Luobgelda, partly Bardoayts (Vičinskas 2015, 178-200; Vičinskas 2017, 434-452), Bicz(z) birbins / Bicž-birbins / bitzbirbins / bicziu birbullis (Vičinskas M1, manuscript prepared for publishing) - described by Matthaeus Praetorius in his manuscript of the late 17th century "Deliciae Prussicae or Prussian Theater" (Deliciae Prussicae, oder Preussische Schaubühne) have already been discussed, also the reliability of M. Praetorius's mythical material on oak has been determined (Vičinskas 2016). The mentioned studies have revealed the tendency of "information noise" and ambiguous authenticity of mythical information, thus, the main focus of this article is the evaluation of reliability of mythical material on fir tree and pear tree. In the course of the present research the following methods have been used: analytical, comparative, structural content analysis, hermeneutic interpretive description.

\section{An overview of studies}

In order to reveal the relevance of verification of M. Praetorius' mythical information on fir tree and pear tree, first of all, the context of the previous studies will be evaluated. Then, in chronological order (from 
the earliest to the latest) there will be presented and evaluated interpretations by more significant researchers of the 19th-21st centuries who were concerned with M. P.'s mythical material on fir tree and pear tree. In the middle of the 19th century, Simonas Daukantas, not naming the exact cited author and the discussed plant, states that " $<\ldots>$ in the seventeenth century, Lithuanians, Samogitians, and Lettians used to visit a [miraculous - Ž. V.] tree in Prussia on the branches of which they used to hang canvas, expensive and more expensive clothes and other vows, and those who were ill and disabled used to go there to touch its trunk so that they would come home recovered and happy" (Daukantas 1976, 87). S. Daukantas's information is likely to be inspired by M. Praetorius's story about the ribbed fir tree that had stood in Nybudžiai forest (see chapter "The ribbed fir tree"). However, the author does not consider the issue of authenticity of the used mythical information. The researcher Petras Klimas (the beginning of the 20th century) also uses the material recorded by M. Praetorius: "Matthaeus Praetorius, by giving the example "The ribbed pear tree" of Nybudžiai, says: "All trees whose trunks were divided and grown up together again, were considered by the people of the old Prussia as sacred, and they still are considered as such" (LM 1995, 153). Nevertheless, this author also does not consider the issue of reliability of information. Mythical data about the fir tree growing near Nybudžiai is identically treated by P. Klimas's contemporary Jonas Bertulaitis (LM 1997, 223). Only M. Praetorius's observation that all trees whose trunks had grown from one another and then grown up together again should be regarded as sacred is viewed by J. Bertulaitis negatively since this information is "not mentioned anywhere else, therefore, it does not seem reliable" (LM 1997, 223). Marija Gimbutiene, in the late 20th century, when discussing the characteristics of the unusual trees, states that "oaks, lindens, birches, maples, pines, and fir trees were often considered as miraculous trees, especially if they were old and powerful or if they had two trunks. People believed that such trees have strong medical properties, no one touched them and did not dare to cut them" (LM 2004, 119). Although the author does not specify the exact source, one can perceive that she partly refers to M. Praetorius's information about the ribbed fir tree of Nybudžiai which had healing powers. 
In the late 20th century, Nijolè Laurinkienè, contrarily to some previously discussed researchers, clearly indicates from where she took the material on the unusual pear tree that had grown in the $\sim$ late 17 th century (Laurinkienè 1996, 119-120). She summarises M. P's mythical information on a special plant in the following way: " $<\ldots>$ it is likely that a god can descend and listen to prayers said by the praying human through the tree which is worshiped and considered sacred" (ibidem, 119-120). The fact that she uses M. Praetorius's mythical material in her work means that she estimates it with favour, especially when referring to M. P.s statement she draws conclusions about the 1 ogic of worshiping the $\mathrm{tr}$ e e s ${ }^{1}$, i.e. the belief that a tree " $\mathrm{X}$ " is patronised by a deity "Y". On the other hand, the researcher, before referring to information of the analysed source, does not discuss the issue of its reliability. Prane StukènaitéDunduliene in her study (the end of the 20th century) dedicated for the meaning of trees - according to the old tradition - uses M. Praetorius's recorded mythic material: "Matthaeus Praetorius writes that in 1664 in Nybudžiai (East Prussia) a two trunk ribbed fir tree was worshiped; in 1673 it burnt. Many people not only from Prussia but also from Samogitia used to come to visit this fir tree and to bring sacrifices. They used to sacrifice shawls, clothes, money: they would put them between the branches of the tree" (Stukènaitè-Dundulienè 2008, 12). It should be noted that although the author indicates the source of the cited material, the rewritten information is not entirely accurate. First, M. P. writes that "pagan pilgrims" from Nadruvia, Skalvia, Samogitia, and Lithuania used to come to the special fir tree. Second, according to P. Stukènaitè-Dunduliené, sacrifices of the comers were placed between the branches of the tree, whereas the original document does not specify the exact placing of sacrifices. In another chapter of her study, P. Stukenaité-Dundulienė is probably confused because she starts the discussion not of a fir tree but of a pine and in parallel provides quite interesting but unfounded observation about a "sketch of a pine" (see Picture 1): "Other trees were worshiped because they seemed similar to humans. For example, in the 17th century in Nybudžiai there grew a sacred pine that had a branch similar to a human hand" (Stukènaitè-Dundulienè 2008, 16). In chapter "Healing trees-totems" the researcher in part wrongly retells M. P's information on

1 All spacings, if not indicated otherwise, are mine - Ž. V. 
the ribbed pear tree: "In Nybudžiai there grew a sacred ribbed pear tree to which there used to come people seeking for treatment" (StukenaitéDundulienè 2008, 25). P. Stukènaitè-Dundulienè states that the ribbed pear tree which had grown in M. Praetorius's garden was a well-known place to "pagan pilgrims" who used to come there in order to be treated; one should think that this action had happened more than once. In the original it is written contrarily, that M. Praetorius had found "a pagan pilgrim" (singular) in his garden near the unusual plant only once, and after the removal of the strange sprout in general " $<\ldots>$ there were no person who would inquire about the tree or who would come to visit the tree except a few children relishing pears" (Pretorijus 2006, 121).

The researcher Elvyra Usačiovaite (21st century), when examining the relicts of the Baltic religion described in the work "Old and New Prussia” by Christoph Hartknoch (Christophori Hartknoch), uses M. Praetorius's material but does not question its reliability (see Usačiovaitė 2013, 45). Similarly behaves another researcher of the 21st century Gintaras Beresnevičius, according to who, M. Praetorius "tells that he had seen a praying Samogitian under a similar pear tree, who, instructed by his senior priest (Lith. vaidilutis), had come to the surroundings of (in this case) Ragainè: under this tree he prayed for health for his seriously ill son" (Beresnevičius 2005, 363-364). In the article which appeared in 2005, G. Beresnevičius incorrectly states that "the pagan pilgrim" had come there in search of help for his son because the original document says that the injured child in need of treatment was a son of the son or a grandson of the comer. This inaccuracy seems strange because in a systematic study of sources of Lithuanian religion and mythology, printed in 2004, G. Beresnevičius conveys the same quotation more precisely: "Praetorius describes that in Nadruvia he had seen a man praying under a sacred tree; it seemed that he had come from Samogitia to pray for health for his grandson, and that he had been sent to the tree by a Samogitian wizard <...>" (Beresnevičius 2004, 216-217). Moreover, most likely due to different translations of the work into Lithuanian language (the first translation was published in the third volume of the "Sources of Baltic religion and mythology", and the second translation - in publications prepared by Inge Lukšaite) there appeared two different versions of the same dialogue. In the third volume of "Sources of Baltic religion and mythology" 
it is translated that the old Samogitian man had been sent to the ribbed plant by a senior priest (Lith. Vaidilutis) (BRMŠ 2003, 233), although in the publication composed by I. Lukšaite, the old Samogitian man had been encouraged to search for a tree suitable for treatment by a priestess (Lith. Vaidilute) (Pretorijus 2006, 117). To sum up, the historian of religions refers to mythical information on the special pear tree provided by $M$. Praetorius but he does not attempt to verify its authenticity. The researcher Jolanta Zabulyte (the early 21st century) in her study "Pine in Lithuanian Traditional Culture" uses M. P's recorded mythical information on fir tree and pear tree. It is interesting that the scientist relies on the translation of the work comprised by I. Lukšaite, therefore, contrary to G. Beresnevičius, she writes " $<\ldots>$ that an old man from Samogitia who had been sent by a priestess (Lith. Vaidilute) prayed beside the ribbed fruit tree asking his God to help his grandchild and to cure his paralysis and dangerously broken bones" (Zabulyte 2014, 36). The author does not analyse the reliability of the intercepted material, nevertheless, tries to justify the belief in the healing power of the ribbed trees by referring to examples from Slavic material: she indicates that the act of getting through the two branches that were grown up together or bent down was also practiced in neighbouring countries (Zabulyte 2014, 36).

The discussed context of the research of Lithuanian mythology of the 19th-21st century has revealed that M. Praetorius's mythical material on fir tree and pear tree, though fragmentarily, but had been used (Daukantas, Klimas, Bertulaitis, Gimbutienè, Laurinkienė, Stukènaitė-Dundulienè, Usačiovaitė, Beresnevičius, Zabulytė), but the authenticity of mythical information had not been attempted to be verified.

\section{The ribbed fir tree}

Before starting the analysis of mythical information on plants provided in the source of the author of the 17th century, it must be remembered that, according to $\mathrm{M}$. Praetorius, not all trees were considered sacred by pagans. In order a plant could be worshiped, it had to meet certain criteria: amaze with its size; to be distinguished by its rarity, i.e. to be somehow un us ua 1 - s pecia $1 /$ s t r a n g e ${ }^{2}$; something important must have

2 In the first section of Chapter 2 of Book 4 of the manuscript, M. Praetorius mentions that a tree on which there grow mistletoes (Viscum album) should be regarded as sacred 
happened near the plant, the issue of the hierarchy of trees was highlighted (Pretorijus 2006, 79). In the second chapter "The narration about other sacred Prussian trees" of Book 4 "On ancient Prussian temples" of the analysed source the author writes about the tradition to worship plants: linden, fir tree, pear tree. With reference to information written by Caspar Hennenberger (Hennenberger 1595, 473), he argues that in Skalvia (in Šakūnai village) there grew a linden which basically corresponded the requirements for worship (was thick, high, ribbed) and to which one secretly at night would bring sacrifices to gods (Pretorijus 2006, 109). The expanded information of M. Praetorius's work should be treated as rewrites, thus, does not require a more detailed discussion. In respect of verification aspect, much more interesting is the text of the third section "Fir tree in Nybudžiai forest" of Chapter 2 of Book 4 which states that in 1664 in the forest section of Nybudžiai parish there stood a strangely conjoined fir tree which the same year was struck by lightning and whose stump burnt during the fire in 1673 (ibidem, 109-113). The fragment enables to reason that M. Praetorius, after moving to Nybudžiai in 1664, immediately started capturing the remnants of paganism observed in the community (Pretorijus 2006, 708). According to him, "pagan pilgrims" of all ages from Nadruvia, Skalvia, Samogitia, Lithuania would come to visit the said plant, they would sacrifice headscarves, trouser bands and other clothes, money (Pretorijus 2006, 113). During adoration they would ask to help to recover and would perform an act that had to ensure this; next to the description, the authentic sketch, drawn with a quill pen, of the fir tree that grew $\sim$ in the late 17th century is provided (see Picture 1).

(Pretorijus 2006: 109). According to him, Prussians thought that "all kind of trees were sacred if their divided trunk was grown up together again" (ibidem: 115). The Baltic criteria for the trees to be sacred in the old written sources are first spoken of by the writer of the end of the 16th century Jonas Bretkūnas (Johannes Bretke); according to him Sudovians had "believed that gods choose their dwellings in hollow trees, so no one has the right to cut the hollow oak" (BRMŠ 2001: 312). This is also partly alluded by the author of the same period Maciej Stryjkowski: "[Czech priest Jerome - Ž. V.] was willingly cutting with an axe one large idol of Perkūnas (Perkun), made of the rugged bark of a tree $<\ldots>$ " (ibidem: 564). In the middle of the 17th century Thomas Clagius, when writing about the oak of Rikjothana, notes that its "branches and leaves, green and in winter and in summer, $\langle\ldots\rangle$ were so intertwined that the rain could never get through and permeate through them; at the top they formed a triple knot $<\ldots$.. " (BRMŠ 2003: 58). All listed assertions have one common sememe - an u n u s u a 1 appearance / structure of a plant. 
Table 1

\section{Authentic information by Matthaeus Praetorius}

\begin{tabular}{|l|l|}
\hline AUTHENTIC INFORMATION \\
\hline 1. & $\begin{array}{l}\text { " }<\ldots>\text { because they were convinced that if someone, being paralyzed or hav- } \\
\text { ing any bone fracture, got through the two branches, he would recover; and } \\
\text { one can still find a lot of people who claim to have experienced the healing } \\
\text { power of this tree and who are not shy to worship the sacred fir tree; this tree } \\
\text { would be also called the ribbed fir tree (Lith. rumbuota egle) and people going } \\
\text { to visit it would say: Let's go to visit the Rombhowa, and if saying quickly: } \\
\text { Let's go / Rommowa. Of course, there were more of such fir trees, because } \\
\text { apart them, there are many places that in Prussian are called sacred: for ex- } \\
\text { ample, Szwente [?Low]zuno, etc., Szwenta mieste, etc." (Pretorijus 2006, 113). }\end{array}$ \\
\hline
\end{tabular}
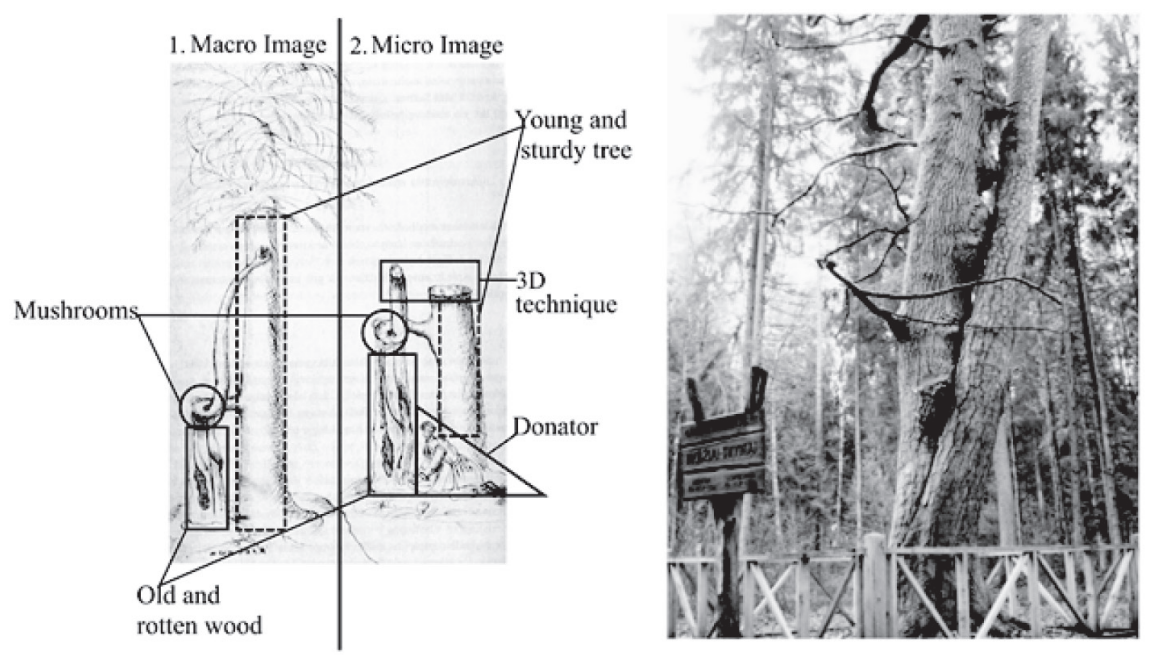

Picture 1. "The ribbed fir tree" (ibidem, 110) (on the left) and "Dubrava Twins" (on the right)

With respect to textual and visual mythical information recorded by M. Praetorius, the scene of adoration can be restored: 1. DONATOR(S). A pilgrim who had come from Nadruvia, Skalvia, Samogitia, Lithuania, and who professes paganism; 2. PLACE OF ACTION. Forest; 3. INANI-

3 "Dubrava Twins" are two trees growing conjoined: an oak (Quercus robur L.) and a pine (Pinus sylvestris L.) (photo by "Vilnesija" (the web page provides author's nickname), the image is created on December 10, 2011.) (Wikipedia.org 2011). 
MATE SACRIFICE(S). Fabrics used to bind (headscarves) or fold (a trouser band), money; 4. THE PURPOSE(S) OF SACRIFICE. Retrieval of the lost health due to paralysis or bone fracture; 5 . ACTION(S) OF SACRIFICE. Getting between or through the branches of a special plant on one's kneels. A close analysis of the picture reveals that the sketch of the ribbed fir tree consists of two drawings of the same object, representing different perspectives: 1) the $\mathrm{mac}$ ro i $\mathrm{mag}$ e provides general characteristics of the plant from the trunk to the top, and 2) the mi croimage focuses on the unusual part of the tree - the concretion. The microimage of the plant is supplemented with the figure of the donator kneeling on the ground. The person is portrayed with a beard, thus, conceived as male. Judging by the posture of the kneeling person, picture attempts to portray the moment of getting "between" or "through" the concretion of the extraordinary tree. Writer of the present article believes that since this magic action is performed kneeling, it testifies for the benefit of reliability of the sketch. Because, reasoning logically, if a man is suffering from bone fracture(s) and (or) paralysis (paralytic stroke?) he has bad control of his body and disrupted balance (see Griškevičius et al. 2010, 35), thus, the donator portrayed in the picture as kneeling on the ground should be consistent with reality. The drawing of "The ribbed tree" seems much more reliable if it is compared with another M. Praetorius's sketch "Oak in Ragaine field" where the ill man who had experienced bone fracture(s) is depicted as climbing into a big oak tree and as if getting through the hole which is high on the tree (Vičinskas 2016, 78-80).

It should be noted that both images are drawn in a special way, providing them with a sense of depth by applying three-dimensional (3D) technique. The trunk of the tree projected on the left side of both of macroimage and microimage has uneven surface (does not have bark?), is as if intertwined from different parts, darker. The ground part of the trunk is blackened-shaded, thus it might represent the hole or the decayed part of the trunk, and in the upper left part of the plant one can notice two semi-circular objects resembling parasitic mushrooms of Polyporaceae family. Absolutely differently appears the plant projected on the right side of the macroimage and microimage, it is more or less straight, bright and does not have any signs of parasitic sprout. Phenomena of conjoining of 
separate parts of a plant are not analysed in detail in the scientific botany . Therefore, it is tricky to support or to deny the authenticity of the picture of M. Praetorius's work with reference to biological science. It is true that on the internet one can find amateur naturalists' articles where such process is recommended to be called as "in oculati o n" ("inoculatio" means "vaccination") $)^{5}$. The identified natural manifestation is attempted to be defined by formulating two different categories of conjoining plants: first, "Hugging Trees" are plants growing next to each other; they as if rub-fold each other, but they do not connect, so they cannot be considered as a single organism; second, "Fused / Conjoined Trees" are such plants whose connection resembles spontaneous vaccination ${ }^{6}$. Despite the fact that the present scientific phenomenon is not thoroughly analysed in the scientific botany, by referring to naturally occurring examples and observations by amateur naturalists, it is considered to be reliable, moreover, since, the strange adoration of conjoined trees, is found to be recorded as a living tradition in the ethnographic material of the 19th-20th centuries:

"Still in serfdom times (around the year of 1840) one ash had two trunks. The ill-person would come and get through the bifurcation of the ash and would become healthy. Healed people would lay sacrifices besides this ash: money, towels. Money would be placed directly on the ground in front of the ash $\langle\ldots\rangle$. Eventually people would peel the ash bark for medicine: they would drink it and pick their teeth; that is why the ash would sooner become rotten $\langle\ldots\rangle$ (recorded by J. Dovydaitis from M. Bagdonavičius, born in 1862, the resident of Padainuvis village)" (Slaviūnas 2007, 296).

Following mythical material on the ribbed fir tree, M. Praetorius immediately provides his own comment-hypothesis. He reasons that in the Prussian land there should be more of such sacred fir trees, and he sup-

4 Only the concretion of roots of a plant is analysed in a greater detail. American scientists, with the help of experiments, have found out that water and infections are transferred through the concretions of roots of trees and much research is conducted in tropical regions to examine the phenomena of "lionism" and "epiphytism" that are directly related to concretions of parts of plants "X" (Stone 1974, 180; Loehle and Jones 1990, 268-271).

5 On the inosculation of trees 1 (Wikipedia.org 2016); On the inosculation of trees 2 (Nativetreesociety.org 2010); On the inosculation of trees 3 (Nativetreesociety.org 2007).

6 On the inosculation of trees 1 (Wikipedia.org 2016); On the inosculation of trees 2 (Nativetreesociety.org 2010); On the inosculation of trees 3 (Nativetreesociety.org 2007). 
ports his argument by providing such toponymic formations as Szwente [?Low]zuno and Szwenta mieste. I. Lukšaite notes that a place name [?Low] zuno has "part of the first letter $\langle\ldots\rangle$ crumbled away in a manuscript $<\ldots>$ " which makes it difficult to be read (Pretorijus 2006, 708), and the second place name Lith. "Šventapile" is reliable (Pèteraitis 1997, 398). For us who are analysing authenticity of $\mathrm{M}$. Praetorius's mythical material, it is important to note that the expanded explanation should be regarded as an interpretation which is based on linguistic analysis of the material and it corresponds to the third feature of M. P.s interpretive system ("linguistic interpretation of mythical information " $\mathrm{X}$ ") and the design of the drawing corresponds to its fifth feature ("the sketch of mythologemes") (Vičinskas 2016, 80-81). It is also interesting that in the fourteenth section "When thunder strikes some sacred Nadruvian thing $\langle\ldots\rangle$ " of Chapter 6 "The narration about worshiping Perkūnas, or a god of thunder" of Book 4 of the analysed work, the author presents a superstition recorded from the living traditions of the $\sim$ late 17th century which says that god Perkünas has the power to change the status of the worshiped tree, at the same time it is also a sign meaning god's dissatisfaction which will be reflected in the future:

Table 2

\section{Authentic information by Matthaeus Praetorius}

\begin{tabular}{|l|l|}
\hline 1. & \multicolumn{1}{|c|}{ AUTHENTIC INFORMATION } \\
"§14. However, it should be noted that in 1664, after the mentioned fir tree \\
had suffered from lightning and God had made it unsuitable for Prussian \\
heterodoxy, old Nadruvians spoke unanimously, "Well, young god Perkūnas \\
took away from us this nice fir tree through which he had done so much \\
good, now we will fall into such hardships and woes that we had not expe- \\
rienced before". They were sure that there would be many big differences. \\
Supposedly, if a young god, i.e. god - Nadruvians still call it like this (as if by \\
nature) - wants to take away the sacred trees, it is also the end to those who \\
worshiped them and used them, and as long as people's memories last, there \\
will be no hope for improvement" (Pretorijus 2006, 249).
\end{tabular}

With reference to what has already been said, it is possible to state that the analysed picture "The ribbed fir tree" depicts trunks of two biologically related trees. The plant which is on the left side of the drawing is old and 
decay; and the plant on the right side is young and strong ${ }^{7}$. Summarizing the sketch from the physical aspect, the drawing projects the twin tree, comprised of or grown from two plants with different properties (the opposition between healthy and unhealthy) that, from the metaphysical point of view, could reflect a human bone divided into two parts / bone fracture. It is possible that for such reason it was believed that getting through (magic action) "between" or "through" the branches of such plants will accelerate the healing of the detached bones. Here, the "coming together" of old-decay and young-healthy plant is the cornerstone that had to encourage the healing of a broken bone. This assumption is also supported by the nature of sacrifices because ill people used to sacrifice fabrics that bind together (headscarves) or fold (a trouser band) certain parts of human body. Finally, mythical material on a fir tree by the author of the late 17th century, both written and visual, except the above mentioned "linguistic interpretation", should be treated as authentic and reliable.

\section{The ribbed pear tree}

Investigating the tradition of tree worshiping, recorded in M. P.'s manuscript, from the point of authenticity, the most comprehensive and the most unique is the fifth section "On a pear tree in Nybudžiai and its overstayer Samogitian" of Chapter 2 of Book 4. The excerpt of the latter section due to its large volume is divided into eight smaller units, next to which comments of the author will be provided.

1. "§5. < ..> In Nybudžiai, in my garden of that time there was such a ribbed pear tree (Lith. rombotha krauszis), i.e. the conjoined pear tree near which I once found an old man kneeling under this tree and murmuring something to his beard, and since I did not notice him at first and was not quiet and gentle enough, he felt disturbed and was preparing to go away. But out of curiosity I detained him to see why he had come to this tree" (Pretorijus 2006, 115).

7 According to Vyacheslav Vsevolodovich Ivanov (Вячеслав Всеволодович Иванов) and Vladimir Nikolaevich Toporov (Владимир Николаевич Топоров), "the most important peculiarities of the Baltic mythology are revealed by the main semantic oppositions, reflecting the characteristics of space and time, social and moral values of the world (favorable and unfavorable to a human): happiness (fate) - disaster (misfortune), life death, even - odd, right - left, top - bottom $\langle\ldots\rangle$, white - black $\langle\ldots\rangle$, old - young, the oldest - the youngest <...” (LM 2004, 348-349). 
I. Lukšaitè accurately notes that the linguistic structure of the first sentence of the expanded fragment reflects the fact that M. Praetorius writes about the past, i.e. he prepared the text when he was not living in Nybudžiai anymore (after 1684) (ibidem, 708). In the sentence it is stated that in M. P.' garden there used to grow a pear of u n u s u a l - s p e c i a l / stra ng e constitution next to which he had found a kneeling praying bearded old Samogitian with whom he tried to make a contactdialogue. The text partially suggests M. Praetorius's knowledge of Lithuanian language and (or) of northwest Samogitian dialect because he names the fruit tree in Lithuanian dialect as "rombotha krauszis", which in the dialect of northwest Samogitians (Telšiai) should correspond to "rombouta kriaušè (-is)", Lith. rumbuota kriaušè (the ribbed pear tree) [translation and simplified transcription by Ž. V.]. In this context one should remember that the written Lithuanian language appeared in the middle of the 16th century (Mažvydas 1547), and the standard Lithuanian language was formed (on the basis of the dialect of Western Aukštaitian (Kaunas)) only at the end of the 19th century - beginning of the 20th century. Due to the fact that some fragments of the analysed work were written by M. Praetorius in $\sim$ the late 17 th century, we should acknowledge that the presented extracts (written in Lithuanian language and (or) Samogitian dialect) should be ascribed to one of the oldest Lithuanian written sources. Thus, in spite of reliability of mythological information recorded in the analysed source, it is valuable from the point of view of Lithuanian language history.

As it has been mentioned above, $\mathrm{t} h \mathrm{~h}$ s $\mathrm{c}$ e $\mathrm{n}$ e circles around M. Praetorius, and this leaves some doubts about the authenticity of the material. What is the possibility that the ribbed pear tree would grow namely in the garden of a clergyman who had attempted to describe cultural history of the Prussian nation? What is more, what is the possibility that he would find a supporter of the pre-Christian religion praying beside the extraordinary tree whom he would later try to interview? Reasoning logically, the possibility that the tree suitable for pagan worship (ribbed, conjoined) would grow namely in M. P.s garden is scarce. Therefore, the hypothesis is raised that the described scene is skilfully imitated or interpreted by the author of the manuscript. Such assumption is strengthened by a proposition, formed in the course of earlier assessments of reliability of 
M. Praetorius's mythical material, that the author of the source had used the formula of random action (FRA) when he was writing down mythical information from contemporaries, because this story encompasses all three "random elements" of the formula: location (L), time (T), presenter (P) (see Vičinskas 2016, 70-71).

2. "I inquired about many things but he only said his name (which I did not know) and claimed to be from Samogitia; I noticed that he was afraid to reveal his affairs to me; I sent to him one of my officers (Lith. potabelis) (the so called peasants, four of which His Grace the Elector of Brandenburg had free of charge appointed to the purposes of my church) and appointed him to question the man cautiously, but still there were no results" (Pretorijus 2006, 115).

It is indicated in the extract that the presenter of information introduces himself but M. Praetorius hurries to assure the reader that this person is not known to him. Following the earlier assertion that the author of the analysed manuscript of the end of 17th century applies FRA, several questions emerge: whether the clergyman really did not know the presenter, was the presenter Samogitian? Writer of the present article believes that there is high probability that the analysed story is interpretive, because the results of verification carried out until now demonstrate that M. Praetorius, unwilling to put his informants, perhaps living in his own parish, in danger, presents to the reader as comers-strangers ${ }^{8}$. Moreover, trying to answer the raised questions, rather important become the above distinguished manifestations of Samogitian dialect, witnessing in favour of reliability of the information, thus an assumption is raised that the analysed dialogue is authentic, but only a partially planned action ${ }^{9}$.

The author of the text mentions the reader that for the collection of the remains of the pagan religion from local residents he uses his officers (Lith. potabeliai), appointed to him by "His Grace the Elector of Brandenburg" for the purposes of the church. He, speaking in modern terms, uses his social-official position and wastes the resources dedicated

8 The verification of M. Praetorius's mythical material on oak and bee god Bičbirbis / Birbulis has revealed that in the text one can found references that suggest that the author of the manuscript had agreed with the presenters of information in advance, which means that conversations were planned, i.e. performed consciously (Vičinskas M1, manuscript prepared for publishing; Vičinskas 2016, 70-71).

9 For more reflections, supporting the assertion that the dialogue is reliable but only a partially planned action, please refer to the fourth comment. 
for the purposes of the church, thus, he could be punished for such behavior. The resources, intended to install and strengthen the positions of the community of the church, are used by the clergyman "vice versa" - to record and archive the remains of the pre-Christian tradition, i.e. to collect and to explain its customs and traditions. All of this can be seen as a motive / reason underlying the attempt to protect the provider and collector. Therefore, it is probable that the author of the source, when assimilating mythical material from contemporaries, used a FRA.

3. "Finally, after many equivocations one of my officers (Lith. potabelis) managed to know that this man was sent here by one priestess from Samogitia. He had to find to his son's child, who has dangerously broken bones and who is paralyzed, a conjoined tree and to put this child through it; the priestess could cure such disease [by using] the power of gods given to such tree. I did not show the man my surprise but asked this Samogitian why he was kneeling and praying under the tree; he said that he had addressed his God and begged for help for his son's child" (Pretorijus 2006, 155).

The third extract witnesses one of the functions of a "Senior priest" $(\text { Lith. Vaidila })^{10}$ - by using a sacred plant as a dwelling of a god "X"to cure a patient who has broken bones, suffers from paralysis (stroke). Mythical information provided in the extract corresponds with the previously discussed information (see Table 1 and Picture 1). In all cases, the main action is getting "through" or "between" the oddly conjoined branches of a tree (fir tree or pear tree) in anticipation of recovery. In fact, the latter example is different from the previously discussed in a way that the process is regulated-supervised by a "Senior priest". Previous mentions about the worship of a fir-tree are more focused on the magic action - getting "through" the adhesion of a tree - therefore, they can be innovations, while the ritual led by a "Senior priest" seems more like an archaic phenomenon.

The commented extract of the text reflects the attitude of a person who had lived in $\sim$ late 17th century and who had professed pagan religion towards the relationship between a plant " $\mathrm{Y}$ " and a god " $\mathrm{X}$ " which is related to the "manifestation of divine powers and feedback through the medium, and hence the special respect for nature" (Balsys 2015, 13). Considering

10 For more information about the identification of this person please refer to the sixth comment. 
mythical information recorded by M. P. it can be argued that respect is shown (prayers are said) not to a plant but to a god which resides in it, and through which the tree acquires special powers that the "Senior priest" is able to manipulate. Discussed mythical information is important because it supports a thesis which was formed during previous studies and which states that the analysed author when writing about respect displayed by his contemporaries "not to the trees but to the angel (Engel) or even more to God (Gott) that had put an angel there" (Pretorijus 2006, 83), designates not the Christian but the pagan tradition (Vičinskas 2016, 71-72). On the other hand, the fact that a "Senior priest" had told the father of the injured child's father to look for a plant proper for adoration-treatment reflects the decline of paganism. It seems that during the described period senior priests no longer have a permanent residence, thus, there is a constant search for location(s) suitable for ceremonies, and this search is carried out by senior priests who use the help of believers.

4. "I tried to explain him: it is good that he had asked God for help, but he had acted as a non-Christian when he had gone to a priestess and expected for such indecent help; I reproached him for such irresponsible behaviour. The old Samogitian began to shiver and shake, thinking that I will deliver him tied to the district authority as a wizard, he was trying to avoid me and asked for mercy adding that now he will have troubles due to public judgement or due to priestess's anger and to his son's child it will be even worse. I explained him that I did not want to punish him, he only has to ask God to forgive his sin and lay his hopes entirely on God and that he will really help his grandson. If only he confesses his sin, he can really believe in me, and I not only wish him the best of luck but that I will also help him and will make sure that he is really delivered wherever he wants" (Pretorijus 2006, 117).

The fourth extract reflects M. P's position towards the person who professes the pre-Christian religion and who is not behaving according to the canons of the church (the phenomenon of the "Self" ant the "Other"). Referring to the text it is evident that by explaining to a pagan person the basis of Christian religion M. Praetorius draws a parallel between the belief system which is understandable to a pagan person (M. P's "Other") and Christian dogma (M. P's "Self"). For example, by saying that if a man faced with a disaster turns to god (in one case this term is used in a general sense and does not identify a particular religious system), he is doing the right thing. Because to pray or to turn to the $\mathrm{tru}$ e God (in another 
case the same term in the text refers to the main object of Christian belief) is a duty and privilege of a responsible believer. But for a Christian to wish for help from pagan gods via a special tree whose powers can be used by a "Senior priest" (Lith. Vaidila) is an anti-Christian act. On the one hand, M. Praetorius shows tolerance to "other" or "alien" religion and partly attempts to understand its internal logic, but he does that in order to clearly show a pagan person his fallacy (religiosity - good, but "inappropriate religiosity" - bad). In this respect, $M$. Praetorius was quite a modern priest because during the period when the use of bodily punishment against the people who were "possessed by the devil" and professed different beliefs (e.g.: judicial interrogations of witches) (BRMŠ 2001, 425-437, 636; 2003, 379-450; 2005, 83-112)) was a widely acceptable method, he proposed sinners: to recognise their sin $\rightarrow$ to start repentance $\rightarrow$ to accept the true God. And by doing so the author as if admits that at the same time - next to each other - there can exist not only one human identity but, on the contrary, different identities in different circumstances of life. That's why he tries to provoke-encourage the transition or change of the identity. To sum up, such way of clergyman's communication, with those who practice different religious tradition, is a behaviour typical to him (at the same time reliable), previously recorded, and more or less described (Vičinskas 2016, 71).

Immediately after M. Praetorius's sermon, the style of communication of the interviewed person changes dramatically probably because he realises that he is communicating with the priest. The presenter begins to shiver and shake in fear. This sudden change reveals three things: 1) it enables to imagine what strict punishments for "religiously inappropriate" behavior were applied in $\sim$ late 17 th century. More information on religious punishments of the similar period can be found in the statutes of the 18th-19th century Lithuanian clergymen estates. According to Povilas Pakarklis, "for the first time when one did not go to the church on holiday $\langle\ldots\rangle$ statutes generally provided monetary punishment of 6 or 8 groschen"11. "For the second time one did not go to the church, statutes

11 " $<\ldots>$ the penalty of 6 groschen for such a crime $\langle\ldots\rangle$ we find $<\ldots>$ in the statutes of diocesan manor of Tauragnai of the year of 1739 and 1746, in the inventory of Dvožecas of the year 1714, in the statute of diocesan manor of Gervaizčiai of the year 1713, in the statutes of Karkažiškiai manor owned by Vilnius Priest Seminary of the year 1740 and 1767” (Pakarklis 1987, 386). 
of estates owned by clergymen $\langle\ldots\rangle$ for this type of crime provided twotimes higher punishment than for the first time $\langle\ldots\rangle^{\text {"12 }}$. Extremely strict punishment is provided in the statutes of clergymen estates for persons who did not go to the church the third time. " $<\ldots>$ Tauragnai manor statues of 1739 and $1746<\ldots>$ provide imprisonment by tying a chain on one's neck, as well as estate punishment (whipping) $\left\langle\ldots>^{13} ; 2\right.$ ) the expressive reaction of the informant seems adequate and convincing, and this reinforces the impression that the dialogue (and mythical material in it) is authentic information; 3) it complements the previously established assumption that the analysed conversation is reliable but only a partly planned action. Probably M. Praetorius had been prepared for the dialogue in advance, i.e. planned the meeting, but the expressive reaction of the interviewed person betrays the fact that the informant was not informed about this.

5. "Then speaking with the old Samogitian kindly and gently I finally managed to learn from him that some Samogitians still believe that such conjoined tress are so wonderfully created not without purpose, in their opinion, they are rightfully considered as sacred; it is supposedly known that those people who had properly worshiped such a tree and followed the directions of worshipers (Lith. maldininkai) (Maldininker) and priestesses (Lith. vaidules) (Weidullen) (thus he called wizards in German, but otherwise maldininks (Maldininks) means Bether, and weidullis (Wei-/dullis) - a wise man, thus, contradictor, who, in his opinion, is wrestling with God in a prayer) would not be left with-

12 "For example, such penalty is determined by the mentioned statute of Karkažiškiai manor of the year 1767 and by the statutes of diocesan manor of Tauragnai of the year of 1739 and 1746" (Pakarklis 1987, 387).

13 "A similar penalty for the third time of such type of offense is determined in the mentioned statute of Karkažiškiai manor of the year 1767. Some statues of church manors for already the second not going to church establishes not only a monetary fine, but also imprisonment by tying a person with a chain on his neck. For example, " $<\ldots>$ the statute of Vazgeliškiai manor of the year of 1788 states that every Sunday and every holiday a foreman must come to the church with all the residents of his district (Lith. dešimtija), with the exception of one person from the family left to guard home. After all, all the other residents must go to the church to attend the Mass, to learn prayers and the matters of belief. If some person on Sunday stays at home, according to the Statute of the manor, for the first offense he must compensate the church 8 skojecs, and for the second time of that type of offense, besides this penalty, the person must incur imprisonment by tying a chain on his neck, and if somebody would not go to the church the third time, besides the above penalties, such person must be also punished by whipping him near the church" (ibidem, 387). 
out help. As far as I noticed, in his heart the old Samogitian approved of this opinion, though (perhaps out of fear) before me now rebuked this different faith of Samogitians" (Pretorijus 2006, 117).

Two previously discussed things are reflected in the fifth extract. First, the logic of people of Baltic origin applied in the adoration of the trees of unusual constitution. Second, M. Praetorius's peculiar tolerance for infidels ${ }^{14}$. It is new and important that in the text it is indicated that the Samogitian man spoke with M. Praetorius in German, it is consider thus because the author of the manuscript notices that the informant " $<\ldots$.

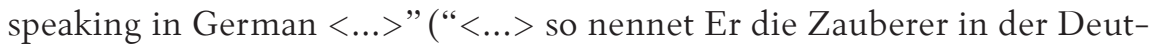
schen Sprache $\langle\ldots>$ ") calls the worshipers (Lith. maldininkai) and senior priests (Lith. Vaiduliai) as "Maldininker" - "Weidullen". According to M. Praetorius, they are not their real names, he corrects the terms by giving Lithuanianized forms of the same words - Maldininks and Wei-/ dullis $^{15}$. The question arises - is there any evidence of knowledge of languages (especially German) of residents of Samogitia of approximately the late 17th century? Can the information be verified? Maybe it is a hint that the presenter was nevertheless a local resident, who, by using the FRA and trying to protect him (at the same time also himself) from religious persecution, was "made" by M. Praetorius as Samogitian? In order to answer the question, perhaps, there can help the Prussian government decree of December 5, 1681 (see Pakarklis 1948, 61) on the pay of maids and houseboys arrived from Samogitia and hired in Klaipeda and on their relationship with Germans, which enables to consider the trips by poor Samogitians to cities in search of work places. Thus, there is high possibility that the Samogitian interviewed by M. Praetorius was actually a working man who had learnt German during his service to German-speaking employers, such assumption is especially reinforced by the previously discussed fragments of Samogitian dialect.

In the analysed extract the change in religious identity is also noted, and this phenomenon is related to "situational identity". The presenter, realising that the confession of pre-Christian tradition will bring him and his

14 See the third and the fourth comments.

15 Such interpretation of material gathered from contemporaries meets the third feature of M. P.'s interpretational system ("linguistic interpretation of mythical information " $\mathrm{X}$ ") (see Vičinskas 2016, 80-81). 
relatives trouble from the authority of the church, begins to explain that the pagan way of life-faith is unacceptable to him. In this context there emerges the term of "ethnicity" and its problems (Eriksen 1993; Hutchinson and Smith 1996; Jenkins 1997). According to Natalija Kataskina, the term of ethnicity derives from Greek language ("ethnos") and usually indicates the identity based on common origin and on the feeling of communal solidarity (Kasatkina 2007, 2). The prevailing usage, although very undefined, because ethnicity is a "term chameleon", takes into account subjectivity, identity and social construction (Kasatkina 2007, 2). Different theoretical views towards ethnicity can be divided into two main directions: 1) p r i m o r d i a lis t i c - the proponents of the first direction think that ethnicity is an objective reality / a given, certain primitive (primordialistic) feature of the mankind; when individual becomes a member of the society (or nation), he realises common origin, cultural or physical similarity or simply closeness to his insiders (ibidem, 2-3; Daukšas and Čiubrinskas 2008, 31; 35); 2) instrum e n ta lis t i c (s i t u a t i o n a l) - ethnicity is a choice, a rational response to some kind of social impact; the proponents of the second direction, reasoning that the expression of ethnicity may change depending on a particular period and local situation, recognise the flexibility of ethnicity (ibidem, 3; ibidem, 38). N. Kataskina as if combines both directions by stating that ethnicity is controlled and has a situational flexibility, but it cannot be created in vacuum, therefore, primordial roots of this phenomenon must be acknowledged (Kasatkina 2007, 3). To us who are analysing mythic information described by M. Praetorius, in this particular case, it is important to recognise the interaction between the directions. Firstly, referring to the text of the late 17th century, the interviewed person assigns himself to a group of people who profess the pre-Christian tradition (those who believe in the healing power of sacral trees "Y", which is provided by a deity " $\mathrm{X}$ " that patronises the plant), which was formed over a long period of time and this is primitive feature. Nevertheless, in response to the real threat (remember the social, religious context of the late 17th century, i.e. Church fines / bodily punishments), he supresses his natural religious identity.

6. "Eventually he confessed that he knew a worshiper, who, if only was able to live safely here near the tree, not only would come here with his all family, 
but supposedly to me it would also be a great happiness, etc., especially if he could sanctify (Lith. iszwentint) the tree - he used namely this word. I asked how and what people are doing when they are sanctifying such tree. I was told different kind of oddities which I intend to present the dear reader elsewhere" (Pretorijus 2006, 117-121) ${ }^{16}$.

The sixth extract complements the previously raised argument that during the analysed period senior priests had deserted many sacred places, no longer had permanent residences suitable for making sacrifices, therefore, became pilgrims or beggars (Balsys 2015, 118-126). Hypothetically there cannot be rejected a possibility that an old bearded Samogitian had also been such a traveller, searching for a place appropriate for the ceremonies. This observation could be supported by three observations: 1. M. Praetorius finds a kneeling-praying donator near a tree corresponding the criteria of pagan adoration. For this reason, it is possible that at that moment he was performing the ritual of a tree consecration; 2. As it will be seen further, in the seventh and eighth excerpts - after the author of the source orders to cut the branch of the pear - it disappears. One can argue that it was probably taken by the old bearded Samogitian who needed it as a sacred object. In this context there must be remembered the previously expanded ethnographic record of the 19th century, which says that believers in the special power of a tree (ash) would finally even peel the bark of the unusually grown plant. This would suggest that all parts of the sacred tree - including surface layer of a trunk - can be used in ceremonies or for treatment; 3. Priests in the written sources of Baltic religion and mythology are predominantly male ("Senior priests"), while the stranger claims that he was sent by a woman ("Priestess") 17 .

16 It should be noted that M. Praetorius's information about consecration of trees in this article will not be analysed separately, because even though a ritual is provided by the same informant, it is not suitable in a thematic aspect. On the other hand, it must be said that presenter's specific knowledge of the pre-Christian religious practices (namely the ceremonies of consecration of trees) allows to assume that he could be a traveling senior priest himself.

17 On the other hand, in documents of the beginning of the 15th century it is written about wizards and witches undesirable by the clergymen: "for God's glory and in order to strengthen faith we determine and command that the public wizards and witches must not be maintained or supported by honorable people, citizens (townspeople) or peasants" (BRMŠ 1996, 488; 502; 504). At the beginning of the 16th century, in widow law described by Simon Grunau, it is stated that "if a woman's husband dies and if she is still young, unmarried men have the right to use her until she will bear a child. 
7. "So that neither this man, nor anyone else had chance to be tempted with idolatry through this tree, in his presence I gathered my men and ordered them to cut down its most important branch to which the Samogitian man had aimed at and due to which the tree could be considered sacred; the Samogitian man was very sad for this. However, strange things happened. 1. While men were cutting down the branch and we all stood around the tree, the cutter was not careful enough for the falling branch, and this heavy branch fell on his feet, so he was ill for 4 weeks and was not suitable for any work, and all this happened in the hottest time of sowing. 2. As a result, people standing around it were so disturbed that they all went away, I myself also walked away from the tree wanting to help the injured, and in the morning that branch was gone" (Pretorijus 2006, 121).

The seventh extract of the text - from the point of view of authenticity - raises some doubts, since the described events correlate with the story described in the fourteenth section of Chapter 1 of Book 4 of the analysed work, which in the sources of Baltic religion and mythology is told several times (used as a stencil). The fourteenth chapter describes an oak in Šventapile dedicated to the honour of deity Gurchas, it should be noted that M. Praetorius, by citing Thomas Treterus's information, notes that Anshelmus I had commanded his workers to cut the sacral Šventapile plant, but the man who had to do this suffered when cutting the tree - it was perceived as a punishment from gods (Pretorijus 2006, 97). Then Bishop Anshelmus I, in order to encourage his workers, took the axe himself and several times cut into the oak - supposedly from here comes the name of the city of Heilig Beyl, in Prussian called Szwenta miesta ("Holy City") (ibidem, 99). After the comparison of both stories (about the cutting of Šventapilè oak and of the ribbed pear tree) it is clear that their scenes are similar: 1) the main agent - a servant of the church; 2) orders to cut a sacred plant, which is a "servant of paganism", 3) however, during the act of cutting the tree a worker is injured, 4) it is considered as a punishment from gods (chronological order of the rewritten information: 1. Enea Silvio Piccolomini (1477) (BRMŠ 1996, 595); 2. Maciej Stryjkowski (1582) (BRMŠ 2001, 564); 3. Annual reports of Vilnius Jesuit College (1583-1611) (ibidem, 632-633); 4. Thomas Clagius (1659)

After that she becomes a priestess (Lith. vaidilute) and has to swear by her life to live in chastity if the community provides for her" (BRMŠ 2001, 95). The old sources also mentioned women enchantresses (ibidem, 424; Ališauskas 2016, 118; 141; 158; 177; 209). 
$(B R M S ̌ 2003,57))^{18}$. The main difference in the stories is that M. Praetorius, unlike Anshelmus I, failed to finish the started work and decided to help the injured man. The author of the present article believes that in order to understand this probably not a random coincidence of stories, one must remember Norbertas Vèlius's comment: "Praetorius wanted to write down the religion and mythology of ancient Prussians $\langle\ldots\rangle$ in Lithuanian customs and beliefs of that time he searched for such information which was witnessed in ancient written Prussian sources $\langle\ldots\rangle$ this desire could impair objectivity because what one is looking for in the living tradition, one is almost always capable to find" (LM 1995, 19). Therefore, it is presumed that some part of the analysed story, in order to increase the value of the material collected from contemporaries, was made by the author as similar to historical sources, that were considered by the author as the "high standard" of information.

8. "I ordered to diligently search for not only in their village, but I myself travelled to various villages, where, I guessed, it could be taken, but I did not manage to know anything relevant, even though here and there I also offered some money. The Samogitian man had also disappeared, and I guessed that namely he had taken this branch. After this there were no person who would inquire about the tree or who would come to visit the tree - except a few children relishing pears“" (Pretorijus 2006, 121).

The last part of the extract provides us with an opportunity to know M. Praetorius's strategy of gathering of information more closely. Previous text fragments have revealed that the author of the manuscript collects the data by traveling in the studied area, applies the FRA, records information by using the help of his assistants, officers (Lith. potabeliai). Besides these things he does not avoid to offer his presenters a monetary reward for information and (or) dialogue.

To sum up, text analysis has revealed that mythical information recorded by M. Praetorius about a pear tree is ambiguous in reliability. Some details of the described story such as location (M. Praetorius's garden), and outcome (removal of the unusual branch from the pear tree which is suitable for adoration) should be treated as unreliable, but the dialogue between

18 Chronological order indicates the course of the rewrites of information: number one indicates the first (from the chronological point of view) historical source where the mentioned scene is found, and number four indicates the last one. 
the author of the manuscript and the presenter of information is authentic. The basis to state that the dialogue between M. Praetorius and "pagan pilgrim" is reliable, but only a partially planned action, is formed by the expressive reaction of the informant, after he realizes that he is speaking about the practice of the pre-Christian religion with the representative of the church (cf. Pretorijus 2006, 81-83). Writer believes that it is probable that M. Praetorius had some information about the pear tree worshiped by the people, therefore, made some kind of ambush to pagan pilgrims coming to visit it. That would explain why he interviews the informant so confidently and purposefully (especially at the beginning of the interview, for example, "I did not show the man my surprise, and asked this Samogitian why he was kneeling under a tree and praying <...>" (ibidem, 155)), but the interviewed does not know the identity of the interviewer. The analysed dialogue is probably a combination of M. Praetorius's recorded information - p la n n e d (M. Praetorius watched the special plant deliberately, with the intention to interview the believers coming to visit it) and $\mathrm{u} \mathrm{n} \mathrm{p} 1$ a $\mathrm{n} \mathrm{n}$ e d (the informant did not plan the interview). In spite of this, it does not diminish the value and reliability of mythical information conveyed in the dialogue, it simply reveals M. Praetorius's methods used for gathering of information from the contemporaries.

\section{Conclusions}

1. The review and analysis of interpretations of mythical information by Matthaeus Praetorius has revealed that the researchers of the 19th, 20th, 21st century (Daukantas, Klimas, Bertulaitis, Gimbutienè, Laurinkienè, Stukènaitè-Dundulienè, Usačiovaitė, Beresnevičius, Zabulytė) used mythical information from M. Praetorius's source but did not question its reliability.

2. The accomplished research has also revealed that M. Praetorius's written and visual mythical information about the fir tree should be considered as authentic. M. Praetorius's mythical information about the pear tree should be threated as ambiguous in reliability. One part of information (location and outcome) is not absolutely reliable, since it has some interpretive features, but the other part (dialogue between M. Pretorijus and "pagan pilgrim") is reliable. 
3. Deep text analysis allows to reason that the material of approximately late 17th century about the pear tree records the shift in religious identity which is related to "situational identity". With reference to the analysed text, the interviewed person ascribes himself to the group of people who practice the pre-Christian tradition that has formed over a long period of time (primordial property). Nevertheless, responding to the occurring real life threat (possible, to him and (or) his relatives), he supresses his natural religious identity (instrumentalist feature).

\section{Abbreviations}

$$
\begin{aligned}
& \text { M. P. - Matthaeus Praetorius } \\
& \text { Ž. V. - Žydrūnas Vičinskas } \\
& \text { 3D - three-dimensional image }
\end{aligned}
$$

\section{Sources and literature}

Ališauskas 2016 - Vytautas Ališauskas. Baltų religijos ir mitologijos reliktai Lietuvos Didžiojoje Kunigaikštystëje (XIV-XVIII a.). Šaltiniu rinkinys. Vilnius: Lietuvių katalikų mokslo akademija.

Balsys 2015 - Rimantas Balsys. Lietuvių ir prūsų pagonybè: alkai, žyniai, stabai. Klaipėda: Klaipedos universiteto leidykla.

Beresnevičius 2004 - Gintaras Beresnevičius. Lietuvių religija ir mitologija: sisteminè studija. Vilnius: Tyto alba.

Beresnevičius 2005 - Gintaras Beresnevičius. Šventybès įžeminimas: pašventinimas i šventumą (pastabos baltų šventumo fenomenologijai). Sambalsiai: studijos, esé, pokalbis, 363-364.

BRMŠ 1996 - Baltu religijos ir mitologijos šaltiniai. Sudarè Norbertas Vèlius, vol. 1. Vilnius: Mokslo ir enciklopediju leidykla.

BRMŠ 2001 - Baltų religijos ir mitologijos šaltiniai. Sudarè Norbertas Vèlius, vol. 2. Vilnius: Mokslo ir enciklopedijų leidykla.

BRMŠ 2003 - Baltu religijos ir mitologijos šaltiniai. Sudarè Norbertas Vèlius, vol. 3. Vilnius: Mokslo ir enciklopedijų leidykla.

BRMŠ 2005 - Baltų religijos ir mitologijos šaltiniai. Sudarè Norbertas Vèlius, vol. 4. Vilnius: Mokslo ir enciklopedijų leidykla.

Čiubrinskas and Kuznecovienė 2008 - Vytis Čiubrinskas, Jolanta Kuznecovienè. Lietuviškojo identiteto trajektorijos. Kaunas: Vytauto Didžiojo universitetas.

Daukantas 1976 - Simonas Daukantas. Raštai, vol. 1. Vilnius: Vaga.

Eriksen 1993 - Thomas Hylland Eriksen. Ethnicity and Nationalism: Anthropological Perspectives. London: Pluto Press. 
Griškevičius and Jarmalienė and Maskeliūnaitė 2010 - Julius Griškevičius, Edita Jarmalienė, Inga Maskeliūnaitė. Žmogaus pusiausvyros parametrų tyrimas. Science - Future of Lithuania (Mokslas - Lietuvos ateitis), vol. 2, no. 4, 35.

Hennenberger 1595 - Caspar Hennenberger. Erclerung der preussischen grossem Landtafel oder Mappen. Konigsberg.

Hutchinson and Smith 1996 - John Hutchinson and Anthony David Smith. Ethnicity. Oxford: Oxford University Press.

Jenkins 1997 - Richard Jenkins. Rethinking Ethnicity: Arguments and Explorations. London and New York: Routledge.

Kasatkina 2007 - Natalija Kasatkina. Etniškumo tyrimai: tendencijos ir esminès sąvokos. Filosofija. Sociologija, vol. 18, no. 4, 2-3.

Laurinkienè 1996 - Nijolè Laurinkienè. Griaustinio dievas Perkūnas. Tautosakos darbai, vol. 5, 119-120.

LM 1995 - Lietuviu mitologija. Sudarė Norbertas Vèlius, vol. 1. Vilnius: Mintis.

LM 1997 - Lietuvių mitologija. Sudarè Norbertas Vèlius, vol. 2. Vilnius: Mintis.

LM 2004 - Lietuviu mitologija. Sudare Norbertas Vèlius ir Gintaras Beresnevičius, vol. 3. Vilnius: Mintis.

Loehle and Jones 1990 - Craig Loehle and R. H. Jones. Adaptive significance of root grafting in trees. Functional Ecology, vol. 4, no. 2, 268-271.

Mažvydas 1547 - Martynas Mažvydas. Catechismusa prasty Szadei, Makslas skaitima raschta yr giesmes del kriksczianistes $\langle\ldots\rangle$. Karaliaučius: Hanso Weinreicho spaustuvè.

Nativetreesociety.org 2007 - On the Inosculation 3. Multitrunk Trees, Woody Vines, and Other Forms. <http://goo.gl/wUD5si> (accessed 2 July 2016).

Nativetreesociety.org 2010 - On the Inosculation 2. Hugging Trees. <http://goo. gl/0vWRzf $>$ (accessed 2 July 2016).

Pakarklis 1948 - Povilas Pakarklis. Kryžiuočiu valstybès santvarkos bruožai. Kaunas: Valstybinė enciklopedijų, žodynų ir mokslo literatūros leidykla.

Pakarklis 1987 - Povilas Pakarklis. Raštai: ateizmas. Vilnius: Mintis.

Pèteraitis 1997 - Vilius Pèteraitis. Mažosios Lietuvos ir Tvankstos vietovardžiai. Vilnius: Mažosios Lietuvos Fondas, Mokslo ir enciklopedijų leidybos institutas.

Pretorijus 2006 - Matas Pretorijus. Prūsijos įdomybès, arba Prūsijos regykla = Deliciae Prussicae, oder Preussische Schaubühne, vol. 3. Vilnius: Lietuvos istorijos institutas.

Slaviūnas 2007 - Zenonas Slaviūnas. Raštai, vol. 2: Liaudies dainos, liaudies muzika ir muzikos instrumentai, papročiai. Vilnius: Vilniaus pedagoginis universitetas.

Stone 1974 - J. E. Stone. Water Conduction in Roots and Root Grafts of Pinus Resinosa. Ithaca, 180.

Stukènaitė-Dundulienė 2008 - Pranè Stukènaitė-Dundulienè. Medžiai senovés lietuviu tikejjimuose. Vilnius: Mokslo ir enciklopediju leidybos institutas.

Usačiovaitė 2013 - Elvyra Usačiovaitè. Baltų religijos reliktai Kristupo Hartknocho veikale „Senoji ir naujoji Prūsija“. Sovijus: tarpdalykiniai kultūros tyrimai, vol. 1, 45

Vičinskas M1 - Žydrūnas Vičinskas. The Verification of Lithuanian Deity Bičbirbis / Birbulis in View of Information Provided by Matthaeus Praetorius, manuscript prepared for publishing.

Vičinskas 2015 - Žydrūnas Vičinskas. Mato Pretorijaus mitinès medžiagos apie Perdoytus, Wejopattis, Gardouten, Bangpitjs, Loubgelda autentiškumas XVI-XVII a. rašytinių 
šaltinių kontekste. Res humanitariae, vol. 18. Klaipedda: Klaipėdos universiteto leidykla, $178-200$.

Vičinskas 2016 - Žydrūnas Vičinskas. Mato Pretorijaus mitinès medžiagos apie ąžuolą verifikacija. Tautosakos darbai, vol. 52 .

Vičinskas 2017 - Žydrūnas Vičinskas. Interpretations of Matthaeus Praetorius Mythical Material on Perdoytus, Wejopattis, Gardouten, Bangpjtjs, Luobgelda in the Works of Lithuanian and Prussian Mythology Researchers of the 19th-21st Centuries. Aktuālas problèmas literatūras un kultūras pētniecībā: rakstu krājums, vol. 22. Liepāja: LiePA, 434452.

Zabulytė 2014 - Jolanta Zabulytė. Pušis tradicinejje lietuvių kultūroje. Sovijus: tarpdalykiniai kultūros tyrimai, vol. 2, 36.

Wikipedia.org 2011 - Dubravos miško dvyniai. <https://goo.gl/mIFdGJ> (accessed 12 November 2016).

Wikipedia.org 2016 - On the Inosculation 1. Inosculation. <https://goo.gl/y3STFF > (accessed 2 July 2016).

\section{Žydrūnas Vičinskas}

\section{DE்L DVIEJŲ MATO PRETORIJAUS VEIKALO PRÚUSIJOS IDOMYBES, ARBA PRÜSIJOS REGYKLA MITINIŲ FRAGMENTŲ: PERPASAKOTA, FIKSUOTA AR PRAMANYTA?}

Santrauka

Tyrinejjant ikikrikščioniškąją baltų kultūrą iškyla ją fiksuojančios raštijos patikimumo klausimas. Vienas turtingiausių rašytinių šaltinių, teikiančių informacijos apie pagoniškąją baltų religiją bei jos kaitą, - Mato Pretorijaus (Matthäus Prätorius) XVII a. pabaigos daugiatomis rankraštis „Prūsijos įdomybès, arba Prūsijos regykla“ (Deliciae Prussicae, oder Preussische Schaubühne). M. Pretorijaus aprašyta mitologine informacija ne kartą naudota XIX-XXI a. mokslininkų, tyrusių baltišką kultūrą ir mitologiją, naudojama dabar bei, greičiausiai, bus naudojama ateityje. Todèl prasminga pamėginti nustatyti tai, kas rankraštyje autentiška / neautentiška. Šiame darbe bandoma verifikuoti $M$. Pretorijaus aprašytos mitinès informacijos, tiesiogiai susijusios su augalais - egle bei kriauše, autentiškumą. Lygia greta aptariamos žymesnių XIX-XXI a. tyrejjų, nagrinèjusių M. Pretorijaus pateiktą mitinę medžiagą apie eglę ir kriaušę, interpretacijos.

M. Pretorijaus mitinių duomenų interpretacijų apžvalga bei analizè atskleidè, jog XIX-XXI a. mokslininkai (Simonas Daukantas, Petras 
Klimas, Jonas Bertulaitis, Marija Gimbutienè, Nijolè Laurinkienė, Pranė Stukėnaitė-Dundulienè, Elvyra Usačiovaitè, Gintaras Beresnevičius, Jolanta Zabulytė) šaltinio mitine informacija naudojosi, tačiau jos patikimumo nekvestionavo. Analizè taip pat parodè, jog $M$. Pretorijaus rašytinè ir vaizdinė mitinè medžiaga apie eglę laikytina autentiška.Vertinant mitinių duomenų apie kriaušę autentiškumą, pasakytina, kad tai nevienareikšmio patikimumo informacija. Viena duomenų dalis (šaltinyje aprašyto veiksmo vieta bei atomazga) nevisiškai autentiška, nes medžiaga turi interpretacijos požymių, o kita dalis (dialogas tarp M. Pretorijaus ir „pagonio piligrimo“) patikima.

Vidinė teksto analizė leidžia samprotauti, jog apytiksliai XVII a. antrosios pusès medžiagoje apie kriaušę užfiksuota religinès tapatybės permaina susijusi su „situaciniu identitetu“. Remiantis tekstu, veikalo autoriaus kalbinamas asmuo save priskiria ikikrikščioniškąią tradiciją praktikuojančių žmonių grupei, kuri susiformavo per ilgą laiko tarpą (primordiali ypatybė). Tačiau jis, reaguodamas ị atsiradusią realią grèsmę jam ir jo artimiesiems, prigimtinį religinį identitetą suskliaudžia (instrumentalistinė ypatybė). 